\title{
Reproductive biology of Nemipterus japonicus (Bloch, 1791) in the trawl grounds along the north-east coast of India
}

\author{
M. V. HANUMANTHA RAO, SHUBHADEEP GHOSH, K. SREERAMULU*, V. U. MAHESH, \\ M. SATISH KUMAR AND M. MUKTHA \\ Visakhapatnam Regional Centre of ICAR-Central Marine Fisheries Research Institute, Pandurangapuram \\ Visakhapatnam - 530 003, Andhra Pradesh, India \\ *Department of Zoology, Andhra University, Visakhapatnam - 530 003, Andhra Pradesh, India \\ e-mail: subhadeep_1977@yahoo.com
}

\begin{abstract}
The reproductive biology of Nemipterus japonicus (Bloch, 1791) along the north-east coast of India was studied during 2012-2015 based on samples from the trawl landings at Digha, Paradeep, Visakhapatnam and Kakinada. Adults dominated the landings. Significant contribution by females was observed in most months of the year. Size at first maturity for females was $15.1 \mathrm{~cm}$. Peak spawning season was during August to February and September to March in the northern and southern regions. Maturity and gonado-somatic index (GSI) were found to correlate well with sea surface temperature (SST). Fecundity increased with length and weight and varied from 13,176 to $1,30,798$. Ova diameter distribution indicated the species to be a multiple/batch spawner.
\end{abstract}

Keywords: Fecundity, Maturity, Nemipterus japonicus, North-east coast, Sex ratio

\section{Introduction}

The north-east coast of the country, comprising of the coastal states of West Bengal, Odisha and Andhra Pradesh, forms a major part of the Bay of Bengal Large Marine Ecosystem region. The region is blessed with one of the largest river drainage systems in the world and hence is very productive with primary production $>300 \mathrm{~g} \mathrm{~cm}^{-2} \mathrm{y}^{-1}$ and chlorophyll a $>0.5 \mathrm{mg} \mathrm{m}^{-3}$. The region is also characterised by marked seasonal fluctuations of oceanographic parameters (Dwivedi, 1993). Threadfin breams form an important demersal fishery resource along this region and is mostly exploited in trawl nets. Threadfin breams recorded during the study period were landed by mechanised trawlers (11-25 m OAL) with engine capacity of 90-250 HP, operating trawl nets, having cod end mesh size in the range $20-30 \mathrm{~mm}$, at 30-100 $\mathrm{m}$ depth. There is high demand for its meat which is used in surimi production. Along the north-east coast, landings of threadfin breams increased from 1,756 t in 1985 to 23,344 $\mathrm{t}$ in 2011 (Ghosh et al., 2015). The resource contributes about $2.3 \%$ to the total trawl landings (Ghosh et al., 2015). Threadfin bream landings are dominated by Nemipterus japonicus (Bloch, 1791) $(60 \%)$ followed by $N$. randalli $(33 \%)$, with negligible quantity of $N$. luteus, $N$. tolu and $N$. peronii (Maheswarudu et al., 2013).
Vivekanandan and Rajagopalan (2009) studied the phenological aspects of threadfin breams off Chennai and reported significant shift in spawning season and changes in the occurrence of spawners with relation to sea surface temperature (SST) from warmer months to cooler months. As understanding the phenological changes in relation to environment is vital in forecasting recruitment, year class success, gear selectivity, sustainable exploitation and management (Bal and Rao, 1984), in the present investigation, reproductive biology was studied in relation to SST. Several studies in the past have focused on the reproductive biology of $N$. japonicus along the coast of India (Kuthalingam, 1965; Krishnamoorthi, 1971; 1974; Vinci, 1982; Murty, 1984; Rao, 1989; Gopal and Vivekanandan, 1991; Rajkumar et al., 2003; Manojkumar, 2004; Kizhakudan et al., 2008); however, there is hardly any documentation for the northern region of the north-east coast comprising the states of Odisha and West Bengal. Moreover, studies from the southern region of the north-east coast (Andhra Pradesh) are more than a decade old. Therefore, the present study investigated the reproductive biology of $N$. japonicus from the northern and southern regions of the north-east coast of India.

\section{Materials and methods}

Samples were collected randomly from the trawl landings at Digha $\left(87^{0} 30^{\prime} 27^{\prime \prime} \mathrm{N} ; 2^{0} 37^{\prime} 7\right.$ ' E) (West Bengal), Paradeep (86 $46^{\prime} 3$ '” N; 20 $17^{\prime} 30^{\prime \prime}$ E) (Odisha, 
Visakhapatnam (83020'35" N; 17044'13" E) and Kakinada $\left(82^{\circ} 16^{\prime} 37^{\prime \prime} \mathrm{N}\right.$; 1700'50" E) (Andhra Pradesh) fishing harbours for the period 2012-2015, after ascertaining the origin of landings at Digha and Paradeep to be from the northern region and landings at Visakhapatnam and Kakinada to be from the southern region along the northeast coast. About 1,302 specimens (length range 48-319 $\mathrm{mm}$ ) were analysed from the northern region and 1,415 (length range $46-287 \mathrm{~mm}$ ) from the southern region. Lengths and weights (whole wet body weight) were measured to the nearest $0.1 \mathrm{~cm}$ and $0.1 \mathrm{~g}$, respectively using a measuring scale and an electronic weighing machine (Sartorius, Germany) and specimens were dissected to confirm the sex. The lengths for each sex was tested for normal distribution using Shapiro-Wilk test. For estimating maturity and ascertaining the spawning periodicity, colour and appearance of gonads, the space occupied in the abdominal cavity and the size of ova were taken into consideration. In the present study, maturity was classified into seven distinct stages (Immature, Developing Virgin/Spent Resting, Early Maturing, Late Maturing, Mature, Running and Partially Spent/Spent) following the International Council for the Exploration of the Seas (ICES) (Lovern and Wood, 1937). Gonads were carefully dissected out from the abdominal cavity and after weighing them to the nearest $0.001 \mathrm{~g}$ were preserved in $5 \%$ buffered formalin for studies on fecundity and ova diameter.

Sex ratio for the population was worked out based on the monthly estimated numbers of females and males in the sample. Monthwise homogeneity of sex ratio (1:1) was tested using Chi-square (Snedecor and Cochran, 1968) in Microsoft Excel. Maturity percentage for each month was calculated by taking the proportion of mature fish in the sample. Specimens with immature, developing virgin/spent resting and early maturing ovaries were rated as immature while those with late maturing, mature and running ovaries were considered as mature. Size at first maturity $\left(\mathrm{Lm}_{50}\right)$ was determined by logistically fitting the fraction of mature fish (late maturing, mature and running ovaries) against length class using the procedure of King (1995). Spawning periodicity over months was estimated from the proportion of gravid and ripe females (mature and running ovaries). Gonado-somatic index (GSI) or the gonad weight in relation to the body weight was calculated using the formula:

$$
\text { Gonado-somatic index }=\frac{\text { Weight of gonad }(\mathrm{g})}{\text { Weight of fish }(\mathrm{g})} \times 100
$$

In mature females with lengths $>200 \mathrm{~mm}$ along the northern and southern regions, ovary subsamples were obtained from the anterior, middle and the posterior regions of mature and running ovaries and fecundity was calculated by multiplying the number of ova in all subsamples to the total ovary weight.

Fecundity $=\frac{\text { Weight of the ovary }(\mathrm{g})}{\text { Average weight of the sample }(\mathrm{g})} \times$ Number of ova in the sample

Relative fecundity was expressed in terms of number of ova per unit weight $(\mathrm{g})$ of the fish. Using the least square method (Snedecor and Cochran, 1968), regression relation was fitted between fecundity and total length as well as weight. Analysis of Covariance (ANACOVA) (Snedecor and Cochran, 1968) was performed to observe the significant differences in slopes. Using a calibrated ocular micrometer under a microscope, the distribution of ova diameter was observed.

Monthly mean values of SST for the northern $\left(19^{\circ} \mathrm{N}-22^{\circ} \mathrm{N} ; 85^{0} \mathrm{E}-87.5^{\circ} \mathrm{E}\right)$ and the southern $\left(14^{0} \mathrm{~N}-19^{0} \mathrm{~N}\right.$; $\left.80^{\circ} \mathrm{E}-85^{\circ} \mathrm{E}\right)$ region of north-east coast between 2012-2015 were obtained from Geospatial Interactive Online Visualisation and Analysis Infrastructure (GIOVANNI) online data of Goddard Earth Sciences Data and Information Services Center (GES DISC) of National Aeronautics and Space Administration (NASA; http:/giovanni.gsfc.nasa.gov/giovanni). Linear regression analyses were performed to elucidate the influence of SST on reproductive performance in both the regions. Statistical analyses were carried out using SPSS ver. 16.0 software (SPSS Inc., Chicago)

\section{Results}

\section{Size distribution and sex}

The length in the northern region ranged from 48 to $319 \mathrm{~mm}$ and in the southern region from 46 to $287 \mathrm{~mm}$. The mean lengths were $173.23 \pm 1.90 \mathrm{~mm}$ and $224.28 \pm 2.70 \mathrm{~mm}$ for males and females in the northern region and $166.94 \pm 1.50 \mathrm{~mm}$ and $210.36 \pm 1.99 \mathrm{~mm}$ for males and females in the southern region. Based on length and maturity, individuals were classified into juveniles $(<110 \mathrm{~mm})$, pre-adults $(110-150 \mathrm{~mm})$ and adults $(>150$ $\mathrm{mm})$. In the northern region, landings comprised $13.20 \%$ juveniles, $15.58 \%$ pre-adults and $71.21 \%$ adults (Fig. 1). Juveniles, pre-adults and adults in the landings of the southern region were $14.31,19.01$ and $66.69 \%$ respectively (Fig. 2). Highest occurrence of juveniles and pre-adults was from November to February and adults from June to October in the northern region. In the southern region, juveniles were predominant from October to April and adults from June to September, whereas pre-adults were encountered throughout the year. 


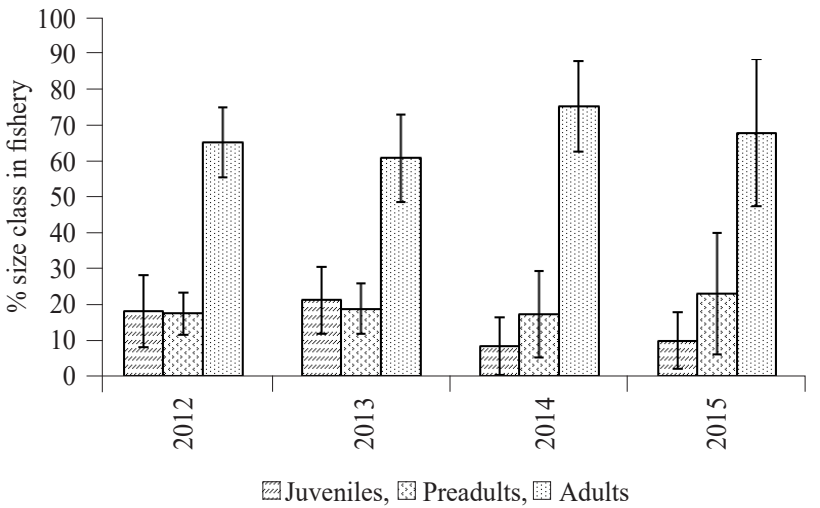

Fig. 1. Size composition of $N$. japonicus in the fishery of the northern region of north-east coast of India

Sex ratio

There was a preponderance of females in the catch throughout the period (Table 1). Annual sex ratio was 2.18 and 1.88 in the northern and southern regions, respectively. Significant dominance $(\mathrm{p}<0.05)$ by females was observed in most months, except for March in the northern region and April and June in the southern region. Length-wise sex ratios in both the regions are presented

Table 1. Monthly sex ratio of $N$. japonicus in northern and southern regions of north-east coast of India

\begin{tabular}{|c|c|c|c|c|c|}
\hline \multirow{2}{*}{ Months } & \multicolumn{2}{|c|}{ Northern region } & \multicolumn{2}{|c|}{ Southern region } & \multirow{2}{*}{$\mathrm{p}$} \\
\hline & $\mathrm{F} / \mathrm{M}$ & $\chi^{2}$ & $\mathrm{~F} / \mathrm{M}$ & $\chi^{2}$ & \\
\hline Jan & 3.59 & 21.1 & 2.66 & 14.3 & 3.84 \\
\hline Feb & 1.95 & 6.6 & 2.65 & 13.8 & \\
\hline Mar & 1.27 & 0.9 & 1.77 & 5.1 & \\
\hline Apr & & & 1.38 & 1.4 & \\
\hline Jun & 2.57 & 12.1 & 1.50 & 2.0 & \\
\hline Jul & 2.74 & 14.2 & 1.78 & 5.0 & \\
\hline Aug & 2.26 & 8.5 & 1.65 & 4.2 & \\
\hline Sep & 2.15 & 8.5 & 1.83 & 5.7 & \\
\hline Oct & 2.16 & 9.3 & 2.00 & 8.3 & \\
\hline Nov & 2.23 & 10.1 & 1.97 & 6.2 & \\
\hline Dec & 1.82 & 5.8 & 1.80 & 5.3 & \\
\hline
\end{tabular}

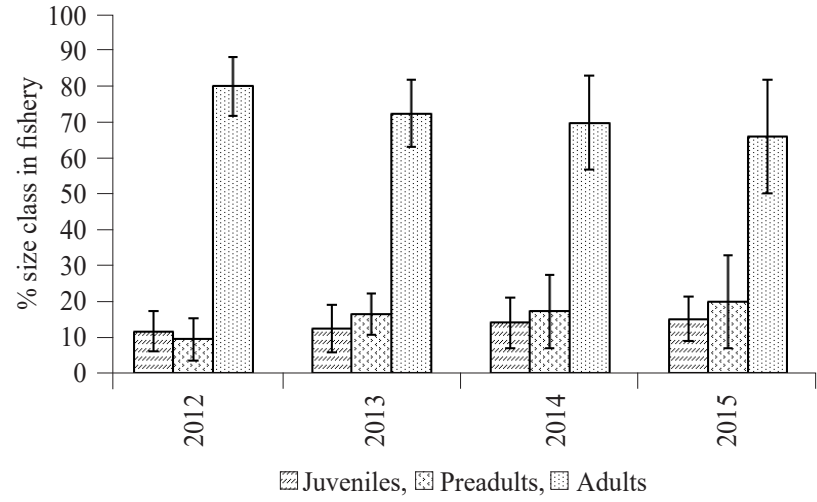

Fig. 2. Size composition of $N$. japonicus in the fishery of the southern region of north-east coast of India

in Tables 2 and 3. Females dominated significantly $(p<0.05)$ in the lower length ranges, whereas males significantly $(\mathrm{p}<0.05)$ dominated the higher length ranges in both the regions. However, SST had no significant influence $(p>0.05)$ in both the regions on the estimated ratios of females and males, as evident in the correlations performed.

\section{Length at first maturity}

Females attained sexual maturity at a size of 154 $\mathrm{mm}$ total length in the northern region and $149 \mathrm{~mm}$ total length in the southern region. Gonadal development in females was observed to commence from $114 \mathrm{~mm}$ in both regions. With no significant difference $(\mathrm{p}>0.05)$ in length at first maturity between the regions, it was estimated at $151 \mathrm{~mm}$ for the pooled population (Fig. 3).

Maturity

Mature individuals were encountered in most months along the northern and southern regions. The proportion varied between years from $40.1 \pm 18.61$ to $56.9 \pm 24.6 \%$ in the northern region and from $43.35 \pm 22.8$ to $52.92 \pm 23.5 \%$ in the southern region. Seasonally, higher proportion of mature individuals was recorded during August to February and September to March in the northern and

Table 2. Length-wise sex ratio in the northern region along north-east coast of India

\begin{tabular}{|c|c|c|c|c|c|c|}
\hline \multirow{2}{*}{$\begin{array}{l}\text { Total length } \\
(\mathrm{TL}, \mathrm{cm})\end{array}$} & \multicolumn{3}{|c|}{ No. of fish } & \multirow{2}{*}{$\begin{array}{l}\text { Sex ratio } \\
(\mathrm{F} / \mathrm{M})\end{array}$} & \multirow{2}{*}{$\chi^{2}$} & \multirow{2}{*}{$\mathrm{p}$} \\
\hline & Male (M) & Female $(\mathrm{F})$ & Total & & & \\
\hline $110-139$ & 1 & 176 & 177 & 176.00 & 88.4887 & 3.84 \\
\hline $140-169$ & 32 & 265 & 297 & 8.28 & 148.493 & \\
\hline 170-199 & 94 & 223 & 317 & 2.37 & 158.494 & \\
\hline $200-229$ & 93 & 169 & 262 & 1.82 & 130.992 & \\
\hline $230-259$ & 108 & 47 & 155 & 0.44 & 77.4871 & \\
\hline $260-289$ & 62 & 12 & 74 & 0.19 & 36.973 & \\
\hline $290-319$ & 20 & & 20 & 0.00 & 9.9 & \\
\hline Total & 410 & 892 & 1302 & 2.18 & & \\
\hline
\end{tabular}


Table 3. Length-wise sex ratio in the southern region along north-east coast of India

\begin{tabular}{|c|c|c|c|c|c|c|}
\hline \multirow{2}{*}{$\begin{array}{l}\text { Total length } \\
\text { (TL, cm) }\end{array}$} & \multicolumn{3}{|c|}{ No. of fish } & \multirow{2}{*}{$\begin{array}{l}\text { Sex ratio } \\
(\mathrm{F} / \mathrm{M})\end{array}$} & \multirow{2}{*}{$\chi^{2}$} & \multirow[b]{2}{*}{$\mathrm{p}$} \\
\hline & Male (M) & Female (F) & $\overline{\text { Total }}$ & & & \\
\hline $110-139$ & 1 & 168 & 169 & 168.00 & 84.4882 & 3.84 \\
\hline $140-169$ & 52 & 362 & 414 & 6.96 & 206.995 & \\
\hline 170-199 & 117 & 250 & 367 & 2.14 & 183.495 & \\
\hline $200-229$ & 185 & 117 & 302 & 0.63 & 150.993 & \\
\hline $230-259$ & 110 & 27 & 137 & 0.25 & 68.4854 & \\
\hline $260-289$ & 26 & 0 & 26 & 0.00 & 12.9231 & \\
\hline Total & 491 & 924 & 1415 & 1.88 & & \\
\hline
\end{tabular}

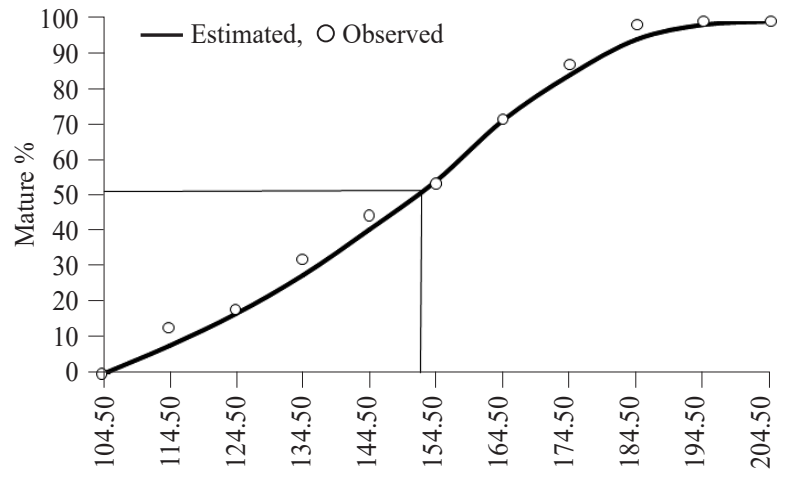

Total length $(\mathrm{mm})$

Fig. 3. Length at maturity for female $N$. japonicus along north-east coast of India

southern regions, with annual average proportion of $49.25 \pm 23.7$ and $48.15 \pm 21.29 \%$, respectively (Fig. 4). Linear regression analysis of SST with maturity revealed significant correlation $(\mathrm{p}<0.05)$ with good model fit $(\mathrm{r}=0.718)$ for the southern region, whereas it was insignificant $(\mathrm{p}>0.05)$ for the northern region.

\section{Gonado-somatic index}

Gonado-somatic index (GSI) for females peaked during September to March in the northern region and October to March in the southern region, which is in conformity with the peak spawning season observed for the species. Annual GSI for the northern and southern regions were $3.18 \pm 0.79$ and $2.92 \pm 0.77$, respectively (Fig. 5). In contrast to the studies on maturity, significant correlation $(\mathrm{p}<0.05)(\mathrm{r}=0.732)$ was observed between SST and GSI in the northern region, but in southern region correlation was insignificant $(\mathrm{p}>0.05)$.

\section{Fecundity and ova diameter}

Fecundity increased with length and weight. Total fecundity ranged from 14,230 to $1,30,798$ and from 13,176 to $1,23,875$ in the northern and southern regions, respectively. Relative fecundity varied from 397 to 611 in the northern region and from 385 to 577 in the southern region with a mean of 529 and 497, respectively. ANACOVA performed between fecundity and total length

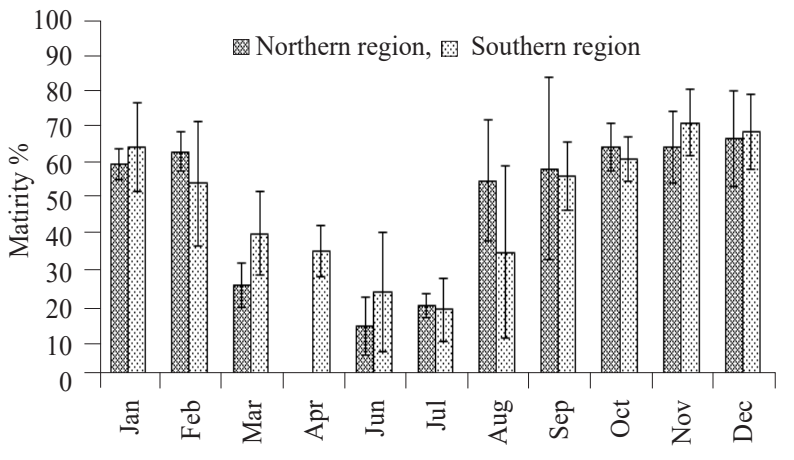

Fig. 4. Proportion of mature females of $N$. japonicus in different months along north-east coast of India

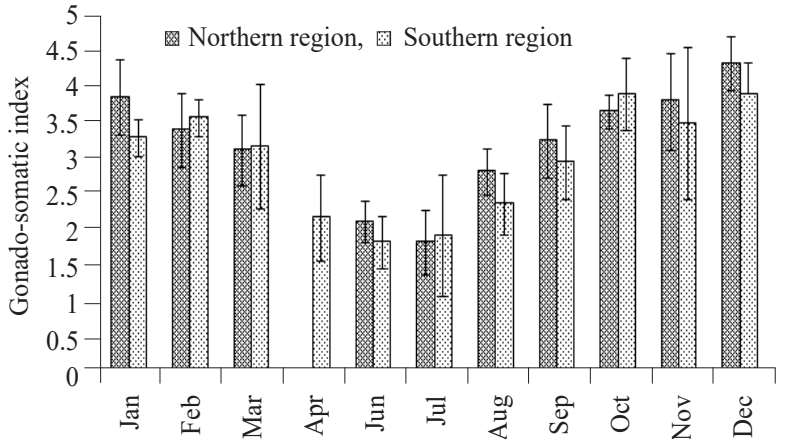

Fig. 5. Gonado-somatic index of $N$. japonicus in different months along north-east coast of India

and weight did not reveal significant variation $(\mathrm{p}>0.05)$ in the regression lines for the two regions and hence a common regression equation was arrived at for the north-east coast, which is given as:

$\log F=0.31725+3.4194 \log L\left(r^{2}=0.99\right)(95 \%$ confidence level $)$

$\log \mathrm{F}=2.3067+1.1710 \log \mathrm{W}\left(\mathrm{r}^{2}=0.99\right)(95 \%$ confidence level $)$

Ova diameter frequency distribution is similar in northern and southern regions (Fig. 6). Multiple ova sizes, from maturing ova to fully mature ova, resembling asynchronous development was observed. In ovaries of late maturing, mature and running stages, mature to fully mature ova ranging in size from 300 to $500 \mu \mathrm{m}$ were recorded. 


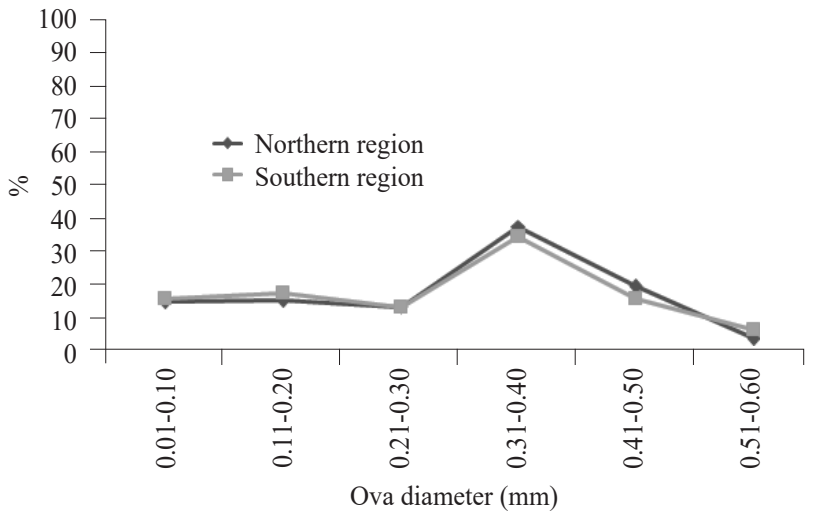

Fig. 6. Ova diameter frequency distribution of $N$. japonicus along the north-east coast of India

\section{Discussion}

In this study, adults dominated the landings along the north-east coast. Single day trawl fishing commences in the southern region by October and ends in February whereas in northern region it begins in November and closes by April. They operate in nearshore shallow waters at 10-20 m depth catching considerable amounts of juveniles and pre-adults. Multiday trawlers which operate round the year in depths beyond $50 \mathrm{~m}$ land adult fishes. The numbers of multiday trawlers are much higher when compared to singleday trawlers. Therefore, majority of the landings observed were adults. Similar observations were made by Kuthalingam (1965), who reported mature specimens from depths beyond $50 \mathrm{~m}$ and juveniles and pre-adults in shallow waters of depth 10-20 m.

Females dominated the landings along the north-east coast. Earlier reports from different parts of the country (Krishnamoorthi, 1974; Murty, 1984; Bakhsh, 1994; Manojkumar, 2004; Kizhakudan et al., 2008; Kerdgari et al., 2009) indicate female dominance particularly in the spawning months. However, the present study found that females dominated throughout the year. Krishnamoorthi
(1974) reported differences in sizes between males and females at Visakhapatnam and Kakinada because of differences in growth rates. Similar observations were recorded in the present study, wherein at lower size ranges, females dominated significantly, whereas in higher size ranges, males dominated significantly. Length at first maturity for females was estimated at $151 \mathrm{~mm}$. Table 4 presents the length at first maturity reported in earlier studies from different parts of the country.

Higher proportion of mature individuals in most months along the north-east coast indicate prolonged spawning periodicity with preference for post-monsoon months which are characterised by low water temperatures favouring their spawning activity. The water temperature ranged from 24.7 to $30.2^{\circ} \mathrm{C}$ during August to February in the northern region and from 26.5 to $29.4^{\circ} \mathrm{C}$ during September to March in the southern region, which was conducive for spawning. GSI was also high during these months indicating it to be the peak spawning months. Kuthalingam (1965) and Manojkumar (2004) encountered more mature individuals from west coast during OctoberFebruary and opined it to be the peak spawning season. Acharya (1990) recorded peak spawning in November and December and Kizhakudan et al. (2008) from September to December. Krishnamoorthi (1971) and Rajkumar et al. (2003) reported September-November to be the peak spawning months off Visakhapatnam. On the contrary, Dan (1977) observed peak spawning between December and February. Murty (1984), from the same location and Kakinada, observed the fish to be a fractional spawner with spawning between August and April. Vivekanandan and James (1986) and Gopal and Vivekanandan (1991) reported extended protracted spawning season off Chennai and Veraval with peak spawning activity between December and March. Lower GSI in the southern region than the northern region could be due

Table 4. Size at first sexual maturity of $N$. japonicus as recorded by earlier authors

\begin{tabular}{llll}
\hline \multicolumn{2}{l}{ Size at first sexual maturity, Lm (mm TL) } & Location & Reference \\
\cline { 1 - 3 } Males & Females & & Krishnmoorthi (1971) \\
n.a. & 165 & Andhra-Odisha & Murty (1984) \\
n.a. & 125 & Kakinada & Vivekanandan and James (1986) \\
n.a. & 145 & Madras & Acharya (1990) \\
n.a. & 135 & Mumbai & Gopal and Vivekanandan (1991) \\
n.a. & 180 & Veraval & Bakhsh (1994) \\
100 mm (TL) & 115 & Red Sea & Rajkumar (2003) \\
n.a. & 128 & Visakhapatnam & Manojkumar (2004) \\
n.a. & 183 & Veraval & Kizhakudan et al. $(2008)$ \\
n.a. & 141 & Saurashtra & Kerdgari et al. (2009)
\end{tabular}

n.a. $=$ Data not available; $\mathrm{TL}=$ Standard length $; \mathrm{FL}=$ Fork length 
to higher SST in the southern region resulting in the fish utilising more energy towards metabolic processes than gonadal development. In general, it is surmised that in the southern region, cooler SST from September to March triggers maturation in adults. In the northern region, because of high freshwater run-off, SST alone could not influence the maturity process. Shift in spawning season and an increase in the occurrence of spawners in months of lower SST is well documented for $N$. japonicus (Vivekanandan and Rajagopalan, 2009).

Linear relationship existed between fecundity and length and weight of the fish. Fecundity estimates were similar to 23,049 to $1,39,160$ reported by Murty (1984) in fishes of 134-199 mm length off Kakinada, but higher than 10,500 to 80,800 reported by Dan (1977) in fishes of 130-209 mm length from the waters of Visakhapatnam. Regression relation between fecundity and total length and fecundity and total weight were similar to those recorded in fishes ranging in length from 165-270 mm by Manojkumar (2004) from Veraval. Mature ovaries contained both maturing and mature ova as suggested earlier by Manojkumar (2004). Oocytes were mature when they attained $0.3-0.5 \mathrm{~mm}$ in dia. Ovarian studies with presence of multiple batches of ova in a single ovary indicate batch spawning in the fish.

The present study documented in detail the reproductive biology of $N$. japonicus from the north-east coast of India for the first time. For fisheries management, it is vital to identify biological characteristics of the species. As managing stocks over a wide geographic area is difficult and often impossible, especially in multispecies and multigear fishery, the study area was divided into northern and southern regions. Lower mean lengths in the southern region indicate higher fishing pressure in this region. As a management measure, for singleday trawlers, cod end mesh size regulation needs to be implemented more strictly for preventing growth-overfishing of the resource. Future research needs to focus on different environmental parameters which could also potentially influence the reproductive biology of $N$. japonicus along this coast.

\section{Acknowledgements}

The authors express their gratitude to the Director, ICAR-CMFRI, Kochi for constant support and encouragement during the study period. Financial support from Indian Council of Agricultural Research, New Delhi is also acknowledged.

\section{References}

Acharya, P. 1990. Studies on maturity, spawning and fecundity of Nemipterus japonicus (Bloch) off Bombay coast. J. Ind. Fish. Ass., 20: 51-57.
Bakhsh, A. A. 1994. The biology of threadfin bream, Nemipterus japonicus (Bloch) from the Jizan Region of the Red Sea. J. King Abdulaziz Univ. (Mar. Sci.), 7: 179-189.

Bal, D. V. and Rao, K. V. 1984. Marine fisheries of India, Tata Mc Graw-Hill Publishing Co. Ltd., 212 pp.

Dan, S. S. 1977. Intra-ovarian studies and fecundity in Nemipterus japonicus (Bloch). Indian J. Fish., 24(1-2): 48-55.

Dwivedi, S. N. 1993. Long-term variability in the food chains, biomass yield and oceanography of the Bay of Bengal Ecosystems. In: Sherman, K., Alexander, L. M. and Gold, B. D. (Eds.), Large marine ecosystems: Stress, mitigation and sustainability, AAAS Press, Washington D C, p. 43-52.

Ghosh, S., Muktha, M., Rao, M. V. H. and Behera, P. R. 2015. Assessment of stock status of the exploited fishery resources in northern Bay of Bengal using landed catch data. Indian J. Fish., 62(4): 23-30.

Gopal, C. and Vivekanandan, E. 1991. Threadfin bream fishery and biology of Nemipterus japonicus off Veraval. Indian J. Fish., 38(2): 97-102.

Kerdgari, M., Valinassab, T., Jamili, S., Fatemi, M. R. and Kaymaram, F. 2009. Reproductive biology of the Japanese threadfin bream, Nemipterus japonicus, in the northern of Persian Gulf. J. Fish. Aquat. Sci., 4(3): 143-149.

Krishnamoorthi, B. 1971. Biology of the threadfin bream, Nemipterus japonicus (Bloch). Indian J. Fish., 18(1-2): 1-21.

Krishnamoorthi, B. 1974. A note on size difference between males and females Nemipterus japonicus (Bloch). Indian J. Fish., 21(2): 608-609.

King, M. 1995. Fisheries biology, assessment and management. Oxford University Press, Oxford, UK, 342 pp.

Kizhakudan, S. J., Thomas, S., Kizhakudan, J. K. and Zala, M. S. 2008. Fishery of threadfin breams along Saurashtra coast (Gujarat) and some aspects of biology of Nemipterus japonicus (Bloch, 1791) and N. mesoprion (Bleeker, 1853). J. Mar. Biol. Ass. India, 50(1): 43-51.

Kuthalingam, M. D. K. 1965. Notes on some aspect of the fishery and biology of Nemipterus japonicus (Bloch) with special reference to feeding behaviour. Indian J. Fish., 12(2): 500-506.

Lovern, J. A. and Wood, H. 1937. Variations in chemical compositions of Herring. J. Mar. Biol. Ass. U.K., 22: 281-293.

Maheswarudu, G., Rao, G. S., Rohit, P., Laxmilatha, P., Ghosh, S. and Muktha, M. 2013. Marine fisheries of Andhra Pradesh: a decadal analysis. Indian J. Fish., 60(3): 27-33.

Manojkumar, P. P. 2004. Some aspects on the biology of Nemipterus japonicus (Bloch) from Veraval in Gujarat. Indian J. Fish., 51(2): 185-191.

Murty, V. S. 1984. Observations on the fisheries of threadfin breams (Nemipteridae) and on the biology of Nemipterus 
japonicus (Bloch) from Kakinada. Indian J. Fish., 31(1): $1-18$

Rajkumar, U., Rao, K. N. and Kingsley, H. J. 2003. Fishery, biology and population dynamics of Nemipterus japonicus (Bloch) off Visakhapatnam. Indian J. Fish., 50(3): 319-324.

Rao, T. A. 1989. Fishery of threadfin breams at Waltair with notes on some aspects of biology of Nemipterus mesoprion (Bleeker). J. Mar. Biol. Ass. India, 31(122): 103-109.

Snedecor, G. W. and Cochran, W. G. 1968. Statistical methods. Oxford and IBH Publishing Co., Calcutta, India, 593 pp.
Vinci, G. K. 1982. Threadfin bream (Nemipterus) resources along the Kerala coast with notes on biology of Nemipterus japonicus (Bloch). Indian J. Fish., 29: 37-49.

Vivekanandan, E. and James, D. B. 1986. Population dynamics of Nemipterus japonicus (Bloch) in the trawling grounds off Madras. Indian J. Fish., 33(3): 145-154.

Vivekanandan, E. and Rajagopalan, M. 2009. Impact of rise in seawater temperature on the spawning of threadfin breams. In: Aggarwal, P. K. (Eds.), Impact, adaptation and vulnerability of Indian agriculture to climate change, Indian Council of Agricultural Research, New Delhi, p. 93-96. 